\title{
IMAGERY OF LOVE AND DEATH IN PLEBERIO'S LAMENT
}

\author{
Ivy A. Corfis \\ University of Wisconsin, Madison
}

Since the seminal studies of Marcel Bataillon, María Rosa Lida de Malkiel, and Stephen Gilman, critics continue to reexamine Pleberio's lament, to define its tradition, tone, message, and purpose within the context of the Comedia and Tragicomedia de Calisto y Melibea. Over the years, critics have classified Pleberio's speech as a thematic epilogue (e.g.. Gilman), a moral summation or peroration (e.g. Lida de Malkiel), a contradictory - if not absurd - ending to the work as a whole (e.g. Bataillon), or an individual man's commentary on his personal plight. As such, in 1964, Bruce W. Wardropper analyzed in detail the nature of the father's lament and concluded that "Pleberio's speech is much too personal, much too anguished in its search for consolation, to be equated with the planctus" (143); but when Wardropper compares Celestina to epic and $15^{\text {th }}$-century elegies, he states that "[i]n designing Pleberio's lament the author of La Celestina had to make use of such vestiges of the older elegiac tradition as were appropriate" (147). He sees Pleberio's "lament on the disappearance of order a summation of La Celestina," for it enables the reader to see the work's theme: that of cupiditas, the "excessive appetite for women and money" (149). "[A] poet like Rojas may understandably dwell, in his intuition of man's tragedy, on the force of cupidity against which man must struggle. The weakness of man versus the power of the Satanic trinity [i.e., World, Love, and Fortune] is a worthy subject of meditation. This line of reflection," it seems to Wardropper, "is the one which Pleberio's elegy directs us to follow" (151-152).

In general, the lament in Celestina is categorized by many critics as a morality piece, exemplary discourse, rhetorical exercise, or a "summation or chorus echoing the loco amor theme of the work," as Flightner reviews the question in 1964 (81). Flightner himself, however, understands the piece as more. 
As he puts it: the "monologue is a continuation of, not an adjunct to, the previous action; [the father's] monologue is a powerful lament by an individual whose suffering is made yet more moving by the realization that, unlike the other characters of the work, Pleberio's dilemma will not soon be terminated by death but will endure" (81). Flightner perceives the lament as developing the loco amor theme and extending it beyond the realm of the human and sensual to the universal contemplation of life, fortune, and death.

It cannot be denied that the predominant tone of the speech is personal, as Wardropper shows-be it serious or ironic; yet as Flightner reminds us, there are clearly interwoven overarching themes of love, life, and death, that take the lament from the level of exclusively personal introspection to that of universal edification, as subsequent studies, such as those by Fraker, Casa and Gerli, continue to demonstrate. In opposition to Bataillon's and Green's view of the soliloquy's unimportance in the work, Charles Fraker maintains that the lament is coherent and essential to Celestina and its world view. Fraker traces the interplay of order and reason - and the consequences of their absence - throughout the work, especially as evinced by key speeches of Calisto, Melibea, and Celestina. Celestina's violent world view, resulting from men placing themselves at the service of their passions, is present in Pleberio's lament and throughout the characters' lives. The same contentious world view is portrayed in other $15^{\text {th }}$-century works, such as Visión delectable (Fraker 521-522). The scenario is not unique to Rojas or Celestina. But it is love that is specifically attacked in the Comedia/Tragicomedia, as explicitly stated in the preliminaries to the text. "Love, compounded with other passions, far from bringing about an increase in the human race, has in fact diminished it," states Fraker. "Five deaths can be charged to love. This fact is Pleberio's target: he rails against the chaos and disorder love produces as he is actually surveying the wreckage it has brought about" (523). Rojas' representation of love as a force for universal ill connects the soliloquy to the heart of Celestina's message, meaning, and structure. In this respect Fraker and Wardropper coincide in the opinion that concupiscence can be evil's ally and thus Fortune and Love can lead man to a fall; and that is precisely the point that Rojas was trying to make in Celestina overall and in Pleberio's lament in particular, an interpretation echoed by Luis Miguel Vicente.

In 1968, Frank Casa also comments on Pleberio's speech. He concludes that Rojas "is not interested in giving a moral lesson [...] Rojas is not judging his characters, he is making them live, but live within a particular conception of life" (29). Casa reads Rojas as portraying man as sinful, but fragile, and impotent against the forces of Fortune, World and Love. "There is a tragic message to the lament as well as to the novel, but it is not that man will be punished for the $\sin$ of lust. The tragedy resides in man's very existence and in his eternal struggle against superior powers" (29). 
In 1976, two important articles appeared on the subject of Pleberio's lament. One, by E. Michael Gerli, views Pleberio's function in the work as one of both exemplification and expression of personal grief (69). Gerli examines Pleberio as the traditional expositor endowed with acute self-awareness and introspection. Gerli holds that Pleberio's lament "represents a rebellion against the ethos of religious and literary convention. It is an anguished plea for individualism as opposed to the bogus security provided by uncritical conformity to literary traditions and Christian views" (73). It is thus that Rojas attacked the established norms of conduct and undermined the philosophical and consolatory topics of his day.

In the second article, Peter N. Dunn underscores the work's ironies that impact on Pleberio's speech. He observes two important meanings in Pleberio's words: "an admission of a general complicity in a shoddy world [...] and [...] the language of commerce applied to the experience of love" (415). ${ }^{1}$ Dunn maintains that Rojas had no need to moralize because the world he portrayed was commonplace in the contemptus mundi tradition. "If Rojas put any other 'message' in his book than that which he advertised, it would seem to indicate the small measure of reality that man can accept" (417).

More recently, Alan Deyermond has revisited the discussion of Pleberio's lament and agrees with Dunn and other critics on the emphasis that Celestina places on economic status and money, an emphasis that is also apparent in the lament. While Deyermond does not overlook the personal sentiment present in the speech (173), he notes the importance of Pleberio's reference to his daughter in terms of his worldly prosperity and economic hopes. Deyermond reaffirms, like Dunn, Rojas' use of bitter irony in the lament and additionally discusses the use of the Salve regina as closure to the frame opened by Calisto's evocation of Psalm 19 with the words "En esto veo, Melibea, la grandeza de Dios."

It cannot be denied that since Pleberio appeared so little in the text prior to the lament and given the minimal interaction between father and daughter -although much information is implied regarding their relationship, ${ }^{2}$ to have Pleberio pronounce the lament evokes many contradictions and raises many questions regarding the nature of Pleberio's grief. Although, as Fraker has shown, the world view that the father describes is not incompatible with what is seen in the prologue and throughout the work, the similarity on the one hand is countered by ironic inconsistency on the other. The importance of economic imagery overall and the "daughter-as-investment" in particular, that Dunn and Deyermond outline, are fundamental to Pleberio's characterization and to how we interpret his words. His materialistic approach to grief adds to the irony found in the lament and elsewhere in the work. ${ }^{3}$ Gerli's view of the irony that rises from Pleberio's undermining of consolatory topics and the ironic use of 
sententiae studied by Gilman and Shipley, to name a few, shape our understanding of Pleberio and the meaning of his lament.

Equally important for interpreting the speech is the concept of love and cupiditas, noted by Wardropper, Flightner, and Fraker, among others, in connection with the idea of Fortune and Fall. The disaster of Melibea's death, the web of intrigue and tragedy woven by the economy of sexual love, clinical love sickness that destroys man's reason through excessive imagination, and the sin caused by such disorder, all give Pleberio cause to rail against World, Fortune and Love, even as his words acquire ironic overtones in light of previous textual events and, as Deyermond reminds us (173-174), Pleberio lacks concern for the condition of Melibea's mortal soul. There is no true expression of grief for her loss outside his own personal complaint.

It is not uncommon in the criticism dedicated to Pleberio's lament to mention other literary elegies as comparisons to Rojas' confection. In addition to the laments in Cárcel de amor, which are obvious counterpoints given Rojas' borrowing of San Pedro's phraseology, the planctus in Jorge Manrique's Coplas and Juan Ruiz' Libro de buen amor are especially brought to bear on the study of Pleberio's discourse. ${ }^{4}$ The Archpriest's use of irony in dedicating an elegy to a go-between, his view of her residing in the glories of heaven, and the use of Achilles' epitaph from the Libro de Alexandre as a model for the bawd's are only a few of the ironic touches Juan Ruiz incorporates into the lament. The unconventional nature of the planctus dedicated to Trotaconventos makes it a logical comparison to Pleberio's speech as a measure of Rojas' irony. Jorge Manrique's Coplas being a masterpiece of conventional elegiac discourse makes it an excellent comparison to show how Rojas adhered to or departed from the mainstream literary commonplace. However, it is not the purpose of this brief study to enter into a word-by-word analysis of these three laments to explicate their manipulation of the topic, both serious and ironic; rather I will focus on one of Pleberio's descriptions of love to exemplify Rojas' appropriation of the tradition and its imagery. Near the end of his lament, Pleberio addresses Love in the following manner:

¡Enemigo de toda razón! A los que menos te sirven das mejores dones, hasta tenerlos metidos en tu congoxosa dança. Enemigo de amigos, amigo de enemigos, ¿jpor qué te riges sin orden ni concierto? Ciego te pintan, pobre y moço. (604-605)

Earlier he accuses Love of being the cause of all the tragedy and death that has occurred to Calisto, Melibea, Celestina and company: "Esto todo causas" (604).

The use of the Cupid image that appears at the end of the quotation given 
above is not surprising nor out of the ordinary, but it is crucial to the identification Rojas establishes between love and evil, for love in this instance is not only blind, in that it affects all capriciously and without warning, but is also blind to all the ill it causes and the good it destroys, thus reinforcing Pleberio's affirmation that love causes death.

The idea of love as death, of course, is commonplace in cancionero poetry,

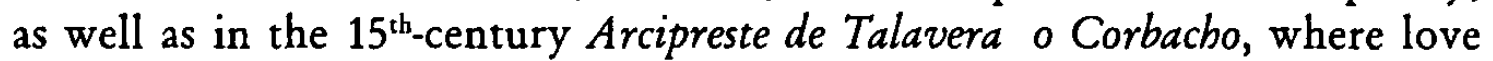
brings about death (e.g., Martínez de Toledo, I: cap. XIV: De cómo por amar acaesçen muertes e daños), and where love causes the seven deadly sins and man's transgression of all ten commandments (Martínez de Toledo, I: caps. XIX-XXXVI). This concept of love's nature was explicated in the $14^{\text {th }}$-century Libro de buen amor, where love is the root of all evil, including the seven deadly sins, as explained in the "Pelea que con [Amor] ovo el dicho Arçipreste" (Ruiz $181 \mathrm{ss}$ ). In specific terms, the Archpriest tells Love: "eres mentiroso falso en muchos enartar; / salvar non puedes uno, puedes çient mil matar" (182cd). Pleberio and Juan Ruiz view similarly the danger of love and the evil that it brings. Both rail against Love and accuse it of murder.

Reiterating the same linkage between love and death is the image of the “congoxosa dança." Pleberio speaks of Love and of Love's dance: Love traps those who are not in love until they have fallen under Love's spell. Once caught in the dance, they are Love's disciples, and, as Pleberio has already declared, Love kills its followers: "Tú matas los que te siguen" (604). In context, the reference to the dance evokes the topical image of the Dance of Death, where Death carries all away, regardless of age, station or wealth. Once more, the imagery of love and death are equated in Pleberio's discourse.

Pleberio continues by calling Love "enemigo de toda razón ... enemigo de amigos, amigo de enemigos," which immediately brings to mind Jorge Manrique's Coplas, Copla 26, where the poet describes his father, Rodrigo, as follows:

¡Qué amigo de sus amigos!

¡Qué señor para criados

y parientes!

¡Qué enemigo de enmigos!

¿Qué maestro de esforçados

y valientes!

¡Qué seso para discretos!

¿Qué gracia para donosos!

¡Qué razón!

¿Qué benigno a los sujetos,

y a los bravos y dañosos, 


\section{un león! (278-279)}

The use of "enemigo"/ "amigo" is a politically charged term and refers to vassalage and alliance. In his edition, Antonio Serrano de Haro gives the following information in the note to Copla 26: "iQué amigo de amigos!], así como [QQué enemigo de enemigos!], era ritual en las escrituras de confederación: «vos yo seré bueno, e leal, e verdadero amigo, y amigo de amigos, e enemigo de enemigos " («Escritura de confederación entre don Rodrigo Manrique y el Conde de Cabra», en [L.] Salazar y Castro, [Historia genealógica de la] Casa de Lara (...) [Madrid, 1696-1697], Pruebas, p. 390), y la yuxtaposición se incorpora a los tratados internacionales de la época y de la primera mitad del siglo XVI" (278). The use of "enemigo de enemigos [...] amigo de amigos" with respect to Rodrigo is a highly laudable quality and denotes the nobleman's loyalty and honesty. To the contrary, in Pleberio's description of Love, Love is "enemigo de amigos, amigo de enemigos." Rodrigo's positive attribute has been inverted to represent love's dishonesty and disloyalty. ${ }^{5}$ Love betrays and murders its followers and friends. It is the traitor, disloyal vassal, and untrustworthy lord. The image underscores what Pleberio has already asserted: Love kills its own; love is murderous.

It is also interesting that Rojas has Pleberio use political phraseology to describe love. In Pleberio's invective against Love, Rojas borrows a term not from general consolatory literature nor from Juan Ruiz' rejection of Love in the "Pelea" nor from the Archpriest's description of Death in his lament for Trotaconventos, but rather Rojas appropriates Jorge Manrique's Coplas, which make frequent use of political vocabulary in their description and praise of Rodrigo's secular activities as lord and knight. Pleberio adopts such terminology to describe how love fits the worldly, materialistic tone of the discourse. Pleberio thinks of Melibea in terms of investment and speaks of Love as part of the body politic that has broken its pact and alliance. Did Pleberio use such terminology and speak so because he believed he had entered into a binding truce with Love ever since he married and settled down at age forty? His earlier words and rhetorical questions, bemoaning how all this tragedy came about, could imply a negotiated peace now broken by Love. The cry of "Cómo me soltaste, para me dar la paga de la huyda en mi vegez?" (603) may suggest that Pleberio believed Love to have breached their contract in a world where even emotions are business agreements that can be bartered. Pleberio's idiolect reflects the preoccupation with economics, negotiations, and alliance that fill his earthly life.

In addition, love is not only the enemy of a friend and friend of an enemy, but the enemy of reason: "enemigo de toda razón." This representation brings to mind the preliminary matter, which states that the implied public for whom the moral lesson was intended is the "mancebos, mostrándoles los engaños que 
están encerrados en sirvientes y alcahuetas" (181) and that the work was composed "en reprehensión de los locos enamorados que, vencidos en su desordenado apetito, a sus amigas llaman y dizen ser su dios. Así mismo fecha en aviso de los engaños de las alcahuetas y malos y lisonjeros sirvientes" (205). The words Pleberio utters at the very end of his lament, at the end of the text, hark back to the beginning of the work: love destroys reason through unbridled desire. As Fraker concluded through his discussion of the work:

Love, assuredly, is not the only passion which dominates the several characters: greed, pride have their place as well. But love is obviously the first to appear, and the first to further the design of fate. (...) Equally important, Celestina, so all-powerful in the plot, owes her very existence to love, as Pleberio points out. Rojas, therefore, not only informs us of the fact that love brings its followers on evil days: by revealing to us the mechanism of Fortune he also specifies how this comes about. Love does its damage by leaving its victims exposed to Fortune, to all the chances and changes of the world, subject to all its conflict, all its lack of purpose. It is abundantly clear, then, that the propositions Pleberio makes about love are only meant to drive home a point Rojas has already made at length throughout the Celestina, that love sows chaos in the world, that love is a great force for ill. (526)

There is obvious thematic and moral similarity between Pleberio's lament and the rest of the work in the portrayal of love. Love destroys order and reason; lack of order and reason brings man to his fall. Pleberio's verbal documentation of the destructive relationship between love and reason is symbolically played out through the many deaths in Celestina. Sempronio, Pármeno, Melibea and Calisto fall to their death as they fall from virtue and fortune. After their fall from the window, Sempronio and Pármeno are beheaded; and Calisto, as a result of his fall from the ladder, has his head broken into pieces and his brains splattered over the paving stones. In three instances falls from fortune are accompanied by "losing one's head" (i.e. reason), literally and figuratively.

In spite of the continuity of images that portray love's destructive force in Pleberio's lament and the work as a whole, the fact that Pleberio is the expositor does make the discourse ironic, as Gerli and Dunn have discussed. Given Pleberio's previous action -or lack thereof- as paterfamilias, his sorrow becomes less pitiable in the reader's estimation. That the topoi of consolation are inverted and do not console and that the father does not meditate on his daughter's afterlife make Pleberio seem materialistic and self-absorbed. $\mathrm{He}$ is more concerned with his own loneliness than with remembering the virtue and goodness of his daughter. As Deyermond points out (173), there is true fatherly 
feeling and Pleberio does express sincere grief at the loss, but the irony of the many questions he finds unanswerable casts a shadow over the heart-felt sentiment. As Dunn brings to fore in his study, of the thirty-eight rhetorical questions Pleberio asks, none is what a father should ask: "How did it happen? Why didn't I know before this?" (415). Moreover, the lament progresses to an ironic crescendo with Pleberio's complaint against the "world" ("Del mundo me quexo porque en sí me crió" 606) -that is, against his own false world of earthly joy and materialistic value- leading to and ending with the "in hac lachrimarum valle" (607), thus sustaining Pleberio's personal cry of woe rather than a "communal consciousness of suffering" (Dunn 417). Much like the Archpriest's lamentation for Trotaconventos, where irony subverts the discourse's genuine grief and belies a true desire to praise and console, Pleberio's lament departs from the consolatory commonplace owing to the particular fabric of his person and circumstances.

This brief examination of only a few lines of Pleberio's speech exemplifies Rojas' familiarity with the elegiac tradition: his inversion of Jorge Manrique's Coplas, the fusion of images of death and love that were commonplace in the Libro de buen amor, in the Dance of Death, in $15^{\text {th }}$-century love poetry, and in texts reproaching love, such as Arcipreste de Talavera, o Corbacho. Rojas handles the existing literary culture aptly and molds it to his own needs. He has Pleberio express the invective against love, like Juan Ruiz before him, in direct appellation to Love, pronouncing a scalding condemnation of its murderous nature. Love obliterates reason and brings those who love to a tragic end. However, even in this consistent presentation of love as destroyer, traced throughout Celestina, Pleberio's words set themselves apart from the rest of the work. Pleberio rails against Love and accuses his old adversary, with which he thought he had come to terms after his fortieth year, of the most foul, vindictive death of his beloved only child. Here a certain irony surfaces, for Pleberio waited and hesitated to give Melibea in marriage. He heard noises in the night but did not follow up on his investigations. His vigilance was lax, perhaps due to his immense paternal love or his economic preoccupations. Regardless of the reason, he must share in the guilt and responsibility he casts at Love's feet. The readers see Pleberio as ironically railing against the World, Love, and Fortune for sins he must also bear. It is truly an odd blend of coherence and inconsistency that make us the amalgam of images that decorate and characterize Pleberio's lament. 
$* * *$

\section{NOTES}

${ }^{1}$ Gerli alludes to the element of commerce in his discussion of the medieval elegiac commonplace, according to which the amassing of material goods is useless, since wealth and possessions cannot pass into the hereafter. Gerli points out how Pleberio inverts the topic, "for he sees the futility of opulence in relation to living" (72).

${ }^{2}$ For development of Pleberio's character and his role in formulation of the action, see Snow.

${ }^{3}$ Again, for ironic elements in the lament, see Dunn; and for irony in the work as a whole, see Ayllón.

4 Gerli compares Pleberio's speech to Manrique's Coplas, with special reference to the commonplace of the disappearance of worldly wealth at death (70-72). The same critic also makes general comparison to Juan Ruiz' planctus (70-71). Wardropper also comments on the two laments (144-45 and 150-51, 146-47).

'For other elements of Manrique's Coplas inverted by Pleberio's discourse, see Gerli 72.

\section{Bibliography}

Ayllón, Cándido. La perspectiva irónica de Fernando de Rojas. Madrid: Porrúa Turanzas, 1984.

Bataillon, Marcel. "La Célestine" selon Fernando de Rojas. Paris: Didier, 1961.

Casa, Frank P. "Pleberio's Lament for Melibea." Zeitschrift für Romanische Philologie 84 (1968): 20-29.

Deyermond, Alan. "Pleberio's Lost Investment: The Worldly Perspective of Celestina, Act 21." Modern Language Notes 105.2 (1990): 169-179.

Dunn, Peter N. "Pleberio's World." Publications of the Modern Language Association of America 91.3 (1976): 406-419.

Flightner, James A. "Pleberio." Hispania 47 (1964): 79-81.

Fraker, Charles F. "The Importance of Pleberio's Soliloquy." Romanische Forschungen 78 (1966): 515-529.

Gerli, E. Michael. "Pleberio's Lament and Two Literary Topoi: Expositor and Planctus." Romanische Forschungen 88 (1976): 67-74.

Gilman, Stephen. The Art of "La Celestina". Madison: U of Wisconsin P, 1956. Green, Otis H. "Did the 'World' 'Create' Pleberio?" Romanische Forschungen 77 (1965): 108-110.

. Spain and the Western Tradition. 4 vols. Madison: U of Wisconsin P, 1968. 1: 112-19. 2: 52-53, 76-77. 3: 202-205.

Hook, David. “'¿Para quién edifiqué torres?"': A Footnote to Pleberio's La- 
ment." Forum for Modern Language Studies 14 (1978): 25-31.

Lida de Malkiel, María Rosa. La originalidad artística de "La Celestina." Buenos Aires: Eudeba, 1962.

Manrique, Jorge. Obras. Ed. A. Serrano de Haro. Madrid: Alhambra, 1986.

Martínez de Toledo, Alfonso. Arcipreste de Talavera o Corbacho. Ed. M. Gerli. Letras Hispánicas 92. Madrid: Cátedra, 1981.

Mendeloff, Henry. "Pleberio in Contemporary Celestina Criticism." Romance Notes 13.1 (1971): 369-373.

Rojas, Fernando de. Comedia o Tragicomedia de Calisto y Melibea. Ed. P. E. Russell. Clásicos Castalia 191. Madrid: Castalia, 1991.

Ruiz, Juan. Arcipreste de Hita. Libro de buen amor: Ed. A. Blecua. Letras Hispánicas 70. Madrid: Cátedra, 1992.

Shipley, George. "Authority and Experience in La Celestina." Bulletin of Hispanic Studies 62 (1985): 95-111.

Snow, Joseph T. "Celestina and Pleberio: When Value Systems Collide." The Medieval Text. Methods and Hermeneutics. A Volume of Essays in Honor of Edelgard E. DuBruck. Eds. W. C. McDonald and G. R. Mermier. FifteenthCentury Studies 17 (1990): 381-393.

Vicente, Luis Miguel. "El lamento de Pleberio: Contraste y parecido con dos lamentos en Cárcel de amor." Celestinesca 12.1 (1988): 35-43.

Wardropper, Bruce W. “Pleberio's Lament for Melibea and the Medieval Elegiac Tradition." Modern Language Notes 79.2 [Special Issue, March] (1964): 140-152.

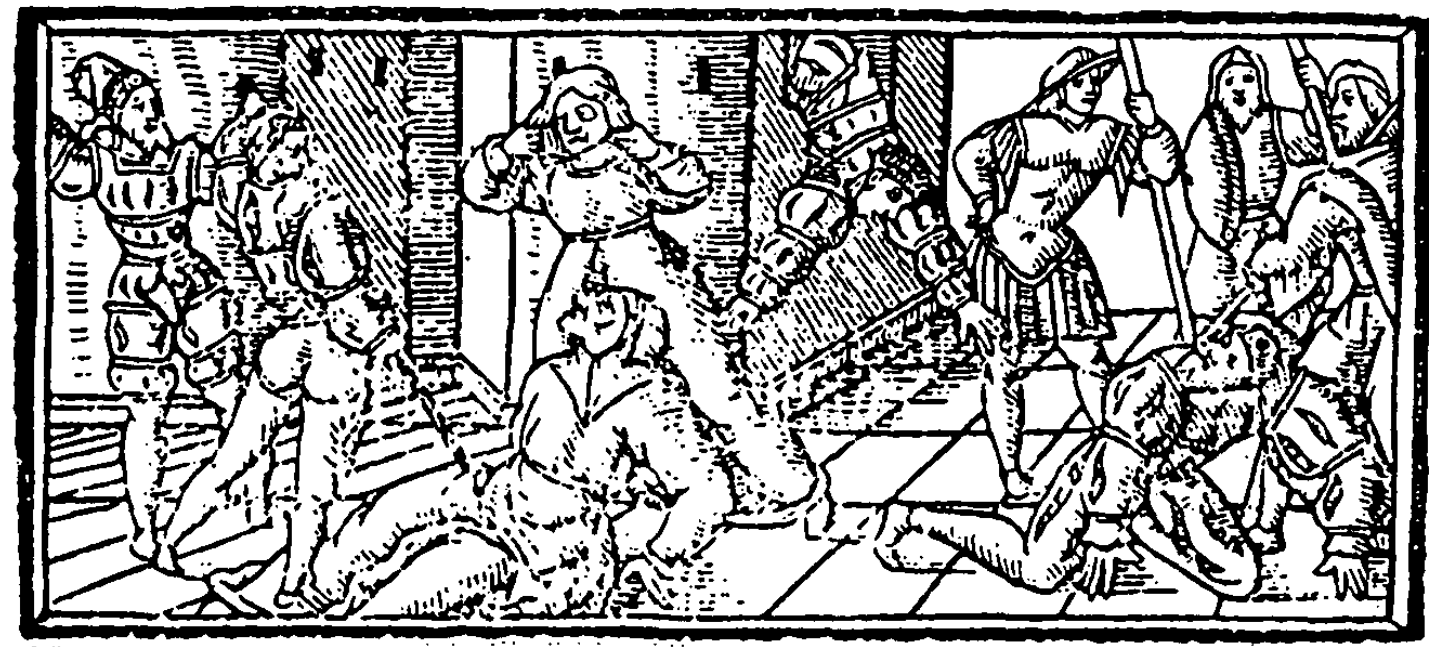

Sevilla 1535 